\title{
The Impact of Tax Morality on Tax Evasion: Evidence of EU Countries
}

http://doi.org/10.21272/bel.5(3).108-112.2021

Oleksiy Mazurenko, ORCID: https://orcid.org/0000-0001-5925-3692

Deputy Head of the Main Department of the State Tax Service of Ukraine in Sumy region, PhD student, Sumy State University, Ukraine

Inna Tiutiunyk, ORCID: https://orcid.org/0000-0001-5883-2940

Doctor of Economics, Associate Professor, Department of Financial Technologies and Entrepreneurship, Sumy State University, Ukraine

Lilia Derkach, ORCID: https://orcid.org/0000-0001-7901-5376

Student, Sumy State University, Ukraine

\begin{abstract}
A set of direct and indirect factors that affect the changing trends of the main indicators of its functioning and determine the key vectors of state policy define the pace of the country's economic development. At the present stage of economic development, along with the objective factors influencing the behavior of economic entities, of great importance are subjective, determined by age, psychological, religious, and other individual characteristics of the individual's perception of economic and political processes in the country. One of the indirect factors of influence is tax morale, the low level of which determines the tendency of taxpayers to evade their tax obligations and negatively affects the level of international tax competitiveness of the country, the share of the shadow sector, the level of corruption. The purpose of the study is to find the nature of the tax morality impact on tax competitiveness indicators of the country. The methodological tools of the research include the analytical method, methods of analysis and synthesis, econometric analysis methods (Panel unit root test, Pedroni panel cointegration tests, Pearson's correlation test, Greanger test, Panel Vector Error Correction Estimate model). The objects of the study are tax competitiveness indicators of the country and the level of tax morale of EU countries for the period 2010-2020. The information base of the study is the data of the World Value Survey and the International Social Science Panel. The results of the analysis showed a significant impact of tax morale on the resulting indicators. Decreasing the level of tax morale leads to an increase in the level of the shadow economy in the country and the volume of tax evasion. The results of the calculations can be useful for representatives of state institutions in the context of the policy of de-shadowing the economy, the fight against corruption, both through restrictive and stimulating tools to influence the behavior of economic entities.
\end{abstract}

Keywords: Tax Morale, Shadow Economy, Tax Competitiveness, Tax Evasion, Trust.

JEL Classification: H20, H71, F38.

Cite as: Mazurenko, O., Tiutiunyk, I., Derkach, L. (2021). The Impact of Tax Morality on Tax Evasion: Evidence of EU Countries. Business Ethics and Leadership, 5(3), 108-112. http://doi.org/10.21272/bel.5(3).108-112.2021.

Received: 21 June 2021

Accepted: 01 August 2021

Published: 13 September 2021

Copyright: (C) 2021 by the author. Licensee Sumy State University, Ukraine. This article is an open access article distributed under the terms and conditions of the Creative Commons Attribution (CC BY) license (https://creativecommons.org/licenses/by/4.0/).

\section{Introduction}

One of the biggest problems of our time, which attracts the attention of scientists and government regulators, is tax evasion. In each country, taxpayers are constantly developing new schemes to conceal income and reduce tax liabilities. Thus, according to the University of London, on behalf of the Socialists and Democrats parliamentary group in the EU Parliament in 2015, EU countries lost more than 824 billion Euros due to tax evasion. It affects the economic development of countries and poses a significant threat to their sustainable development and international competitiveness. Some subjective and objective factors determine the propensity of economic entities to evade taxation. Thus, if the objective factors include factors that depend on government policy and efficiency (level of taxation, the effectiveness of financial monitoring and control 
procedures, the level of penalties), the subjective factors include intangible motives that are not directly determined by the aspirations of economic entities to enrichment, and due to traditions in society, psychological and religious characteristics of the individual. One of the most influential subjective factors that determine the propensity to evade taxation is the level of tax morale of the population. Tax morality is determined by some factors, including the tendency to feel guilty for the offenses, the level of honesty in society, the culture of the population (Doerrenberg \& Peichl, 2018; Kirchgässne, 2011). No less important factor in raising tax morale is the feeling of security and justice in the country.

The population's understanding of the areas of spending budget funds (including tax revenues) and the high quality of public services makes the individual responsible for completing their obligations to the state. The level of tax culture in society has a significant impact on the level of tax morality. Compliance with the tax norms by most taxpayers in society increases the tax liability of other taxpayers and leads to a reduction in tax evasion in the country. Under these conditions, the fulfillment of tax obligations begins to be considered by taxpayers as a mandatory and necessary tool for the country's economic growth and social protection of its population. Despite the significant interest of scientists in this issue, the subjective factors of tax evasion are poorly understood and their relationship with the level of economic shadowing and tax competitiveness of the country needs further analysis.

\section{Literature Review}

Today, issues of tax morality are quite actively studied by scientists around the world. Thus, H. Weck (1983), based on econometric modeling, built a model of the dependence of the level of shadowing of the economy on the share of direct and indirect taxes, the volume of insurance premiums in GDP, public perception of the tax burden (change in the direct taxes), the level of government regulation (employees in the labor force), the amount of real income per capita and the level of tax morale. The author used survey data as data on the level of tax morale of the population. Based on the calculations, the author concludes that the tax burden on direct taxes, the level of government regulation, and tax morale have a statistical impact on the shadow economy. The highest correlation coefficient is in tax morale. Thus, the author emphasizes the need to consider this factor in the development of measures to de-shadow the economy and the inadmissibility of neglecting its impact.

B. Torgler, in the study of factors in the formation of tax morality, in addition to such generally accepted factors as age, gender, marital status, and employment status, considered the level of trust in government and the legal system, decentralization, cultural factors, religion. According to the calculations, the author proved the positive impact of these factors on the tax morale of the population; the low efficiency of state institutions negatively affects the tax morale. Religion has a strong influence on the level of tax morality. Yes, believers have a higher level of tax morality. In his subsequent research, the author has the presence of differentiation in the levels of tax morality of different religions. Compared to Protestants, Catholics have a relatively higher level of tax morality. J. Scholz and N. Pinney (1995) note that a higher risk of liability for tax evasion leads to an increase in the level of tax morality in society.

In this context, the authors attach great importance to the principle of equality. Citizens are more willing to fulfill their tax obligations provided they are confident that other members of society are doing the same. At the same time, M. Wenzel (2005) argues that the individual is biased towards other members of society. Under any circumstances, the individual evaluates the other community members as having a lower level of morality than themselves. If this fact is neutralized, the amount of tax evasion is significantly reduced. The analysis of the scientific literature allows us to conclude about the low level of research of non-economic drivers of tax evasion. The assessment of the level of tax morale of the population is carried out mainly based on the results of a sociological survey and usually characterizes the realities of the behavior of taxpayers of a particular country.

\section{Methodology and Research Methods}

The methodological basis of the study are methods of economic and mathematical analysis and modeling. We will test the hypothesis of the relationship between the level of tax morale $\left(T M_{i}\right)$ and indicators of tax competitiveness of the country $\left(Y_{i t}\right)$ using the following model:

$$
Y_{i t}=\alpha_{i t}+\beta_{1 t} T M_{i}
$$

\section{Results}

A reason for studying the relationship between the tax morale of the population and the level of the shadow economy is to assess its level. Empirical calculations will be based on a survey conducted by representatives of the International Social Science Panel and World Value Survey data. At the first stage, we will carry out the descriptive analysis of the data series (Table 1). 
Table 1. Descriptive Statistics of Data Series

\begin{tabular}{|l|c|c|}
\hline \multicolumn{1}{|c|}{ Level } & Mean & Std. Deviation \\
\hline Tax morale (TM) & 0.514125 & 0.1452145 \\
\hline Tax revenues/GDP (TR) & 0.362547 & 0.2415321 \\
\hline Corruption (C) & 0.5365214 & 0.32568599 \\
\hline Shadow economy (SE) & 0.6584585 & 0.2154588 \\
\hline Illicit Financial Flow (IFF) & 0.7214521 & 0.2325614 \\
\hline
\end{tabular}

Source: Compiled by authors

The results of the analysis indicate a significant variability of the analyzed indicators. The level of corruption is the most important standard deviation. At the same time, the country's tax morale level is characterized by the lowest variability, and its average values are the lowest among the analyzed indicators. To determine the nature of changes in the researched time series, we will examine their stationarity.

Table 2. Panel Unit Root Results for Tax Morale and Indicators of Tax Competitiveness

\begin{tabular}{|c|c|c|c|c|}
\hline \multirow{2}{*}{ Variables } & \multirow{2}{*}{\multicolumn{2}{|c|}{ Test statistics }} & \multicolumn{2}{|c|}{ Individual intercept } \\
\hline & & & Level & First difference \\
\hline \multirow{6}{*}{ TM } & \multirow{2}{*}{ LLC } & Statistic & 0.2354 & -3.75 \\
\hline & & $\mathrm{p}$-value & 0.8547 & $0.000^{*}$ \\
\hline & \multirow{2}{*}{ IPS } & Statistic & 0.7584 & -1.3256 \\
\hline & & $\mathrm{p}$-value & 0.6258 & $0.000 *$ \\
\hline & \multirow{2}{*}{ Hadri } & Statistic & 0.3256 & -2.6258 \\
\hline & & $\mathrm{p}$-value & 0.2142 & $0.000 *$ \\
\hline \multirow{6}{*}{ TR } & \multirow{2}{*}{ LLC } & Statistic & 0.6325 & -1.3256 \\
\hline & & p-value & 0.5244 & $0.000 *$ \\
\hline & \multirow{2}{*}{ IPS } & Statistic & 0.3255 & -5.6254 \\
\hline & & $\mathrm{p}$-value & 0.2145 & $0.000 *$ \\
\hline & \multirow{2}{*}{ Hadri } & Statistic & 0.6985 & -4.2568 \\
\hline & & p-value & 0.1254 & $0.000 *$ \\
\hline \multirow{6}{*}{$\mathbf{C}$} & \multirow{2}{*}{ LLC } & Statistic & 0.9658 & -7.5215 \\
\hline & & $\mathrm{p}$-value & 0.7548 & $0.000 *$ \\
\hline & \multirow{2}{*}{ IPS } & Statistic & 0.2645 & -5.6215 \\
\hline & & $\mathrm{p}$-value & 0.6325 & $0.000 *$ \\
\hline & \multirow{2}{*}{ Hadri } & Statistic & 0.3256 & -3.2654 \\
\hline & & $\mathrm{p}$-value & 0.4578 & $0.000 *$ \\
\hline \multirow{6}{*}{$\mathbf{S E}$} & \multirow{2}{*}{ LLC } & Statistic & 0.3256 & -8.2564 \\
\hline & & $\mathrm{p}$-value & 0.4258 & $0.000 *$ \\
\hline & \multirow{2}{*}{ IPS } & Statistic & 0.3266 & -2.6585 \\
\hline & & p-value & 0.7458 & $0.000 *$ \\
\hline & \multirow{2}{*}{ Hadri } & Statistic & 0.9658 & -6.8547 \\
\hline & & $\mathrm{p}$-value & 0.1566 & $0.000 *$ \\
\hline \multirow{6}{*}{ IFF } & \multirow{2}{*}{ LLC } & Statistic & 0.3658 & -8.6254 \\
\hline & & $\mathrm{p}$-value & 0.2158 & $0.000 *$ \\
\hline & \multirow{2}{*}{ IPS } & Statistic & 0.3259 & -5.6589 \\
\hline & & p-value & 0.5478 & $0.000 *$ \\
\hline & \multirow{2}{*}{ Hadri } & Statistic & 0.6589 & $-7 / 4582$ \\
\hline & & p-value & 0.5248 & $0.000^{*}$ \\
\hline
\end{tabular}

Note: * significance at the $1 \%$ level

Source: Compiled by authors

For all analyzed indicators, the calculated value is less than the absolute values at a $1 \%$ level of statistical significance. It allows us to reject the hypothesis of the presence of a single root in time series. It indicates the non-stationary nature of the analyzed data series. At the next stage, we test the hypothesis of cointegration of the researched data series.

Table 3. Pedroni Panel Cointegration Tests Results

\begin{tabular}{|c|c|c|c|c|c|}
\hline \multicolumn{3}{|c|}{ Within dimesion (panel statistics) } & \multicolumn{3}{|c|}{ Between-dimension } \\
\hline Test & Statistic & Prob. & Test & Statistic & Prob. \\
\hline Panel v-Statistic & -1.62547 & 0.8547 & Group rho-Statistic & -1.8569 & 1.55874 \\
\hline Panel rho-Statistic & -1.52456 & 0.3625 & Group PP-Statistic & -1.25145 & $(\mathbf{0 . 0 0 5 8}) *$ \\
\hline Panel PP-Statistic & -2.03652 & $(\mathbf{0 . 1 5 4}) *$ & Group ADF-Statistic & -2.36589 & -1.9658 \\
\hline Panel ADF-Statistic & -1.78541 & $(0.0658) * * *$ & & & \\
\hline \multicolumn{3}{|c|}{ (weighted statistic) } & & & \\
\hline Panel v-Statistic & -1.8745 & 0.8547 & & & \\
\hline Panel rho-Statistic & -1.2415 & $(\mathbf{0 . 0 6 5 8}) * * * *$ & & & \\
\hline Panel PP-Statistic & -2.7458 & $(\mathbf{0 . 0 0 3 2}) * *$ & & & \\
\hline Panel ADF-Statistic & -1.62145 & $(0.0547) * *$ & & & \\
\hline
\end{tabular}

Note: *,**,*** significance at the $1 \%, 5 \%$ and $10 \%$ levels

Source: Compiled by authors 
The results of the calculations of the Pedroni test shown in Table 3 allow us to reject the hypothesis of the lack of cointegration between the analyzed indicators by $1 \%, 5 \%$, and $10 \%$ significant levels. The relationship between tax morale and the country's competitiveness indicators will be assessed using Pearson correlation analysis. The data show that Corruption, Shadow economy, and Illicit Financial Flow are positively correlated with Tax morale. The correlation coefficient for all indicators is less than 0.8 , which allows us to reject the hypothesis of multicollinearity between them. The values of correlation coefficients for all analyzed indicators exceed 0.7 , which indicates a significant impact of tax morale on the studied indicators.

Table 4. Pearson's Correlation Analysis Results

\begin{tabular}{|l|c|c|c|c|c|}
\hline & TM & TR & C & SE & IFF \\
\hline TM & 1 & & & & \\
\hline TR & 0.7581 & 1 & & & \\
\hline C & 0.7158 & 0.8189 & 1 & & \\
\hline SE & 0.7954 & 0.7985 & 0.8547 & 1 & 1 \\
\hline IFF & 0.7562 & 0.8145 & 0.8825 & 0.8757 & \\
\hline
\end{tabular}

Note: ** Correlation is significant at the 0.01 level (two-tailed)

Source: Compiled by authors

The reliability of the obtained results and the nature of the relationship between the indicators will be determined using the evaluation of VECM model parameters. The presence of short-term impact of tax morale on indicators of tax competitiveness of the country will be determined using the Granger test.

Table 5. Greanger Test

\begin{tabular}{|c|c|c|c|c|c|c|c|}
\hline \multirow{2}{*}{$\begin{array}{l}\text { Dependent } \\
\text { variables }\end{array}$} & \multicolumn{5}{|c|}{ Short run } & \multirow{2}{*}{$\frac{\text { Long run }}{\text { ECMt_1 }}$} & \multirow[t]{2}{*}{ Conclusion } \\
\hline & $\Delta(\mathrm{TM})$ & $\Delta(\mathrm{TR})$ & $\Delta(\mathrm{C})$ & $\Delta(\mathrm{SE})$ & $\Delta$ (IFF) & & \\
\hline$\Delta(\mathbf{T M})$ & - & $\begin{array}{c}-3.52145 \\
(0.0413)^{* * *}\end{array}$ & $\begin{array}{c}-4.21756 \\
(0.0685)^{* *}\end{array}$ & $\begin{array}{c}-6.42514 \\
(0.0859) * * *\end{array}$ & $\begin{array}{c}-7.5215 \\
(0.0425)^{* *}\end{array}$ & $\begin{array}{c}-0.6985 \\
{[-6.5247]}\end{array}$ & $\mathrm{TM}>\mathrm{TR}$ \\
\hline$\Delta$ (TR) & $\begin{array}{c}-3.52145 \\
(0.0413)^{* * * *}\end{array}$ & - & $\begin{array}{c}-0.32856 \\
(0.0325)^{* * *}\end{array}$ & $\begin{array}{c}-3.2565 \\
(0.0155) * * *\end{array}$ & $\begin{array}{c}-0.36624 \\
(0.0745)^{* *}\end{array}$ & $\begin{array}{l}-0.02365 \\
{[-2.5789]}\end{array}$ & $\mathrm{TR} \neq>\mathrm{TM}$ \\
\hline
\end{tabular}

Note: *, **, *** significance at the $1 \%, 5 \%$ and $10 \%$ levels

Source: Compiled by authors

The data in Table 5 confirm the existence of a one-way causal relationship between indicators at $10 \%$ and $5 \%$ levels of statistical significance. Thus, increasing the level of tax morality in society will reduce the level of shadowing and corruption in the country, and vice versa - with a decrease in the level of tax morality, the volume of shadow financial transactions and corruption in the country will increase significantly. A long-term relationship between the indicators will be analyzed using Panel Vector Error Correction (Table 6).

Table 6. Panel Vector Error Correction Estimate Results

\begin{tabular}{|c|c|c|c|c|c|}
\hline Error Correction & $\Delta(\mathbf{T M})$ & $\Delta(\mathbf{T R})$ & $\Delta(\mathbf{C})$ & $\Delta(\mathbf{S E})$ & $\Delta($ IFF $)$ \\
\hline \multirow{2}{*}{$E C T_{t-1}$} & -0.14785 & -0.25658 & -0.17851 & -0.21458 & -0.23658 \\
\hline & {$[-4.25457]$} & {$[-1.32451]$} & {$[-0.58036]$} & {$[-4.25457]$} & {$[-4.25457]$} \\
\hline \multirow{2}{*}{$\Delta($ TM $(-1))$} & -0.29526 & 0.01226 & -0.32985 & 0.00786 & 0.00658 \\
\hline & {$[-3.43526]$} & {$[0.12722]$} & {$[-1.90976]$} & {$[0.07529]$} & {$[0.08585]$} \\
\hline \multirow{2}{*}{$\Delta(\operatorname{TR}(-1))$} & 0.68288 & 0.00313 & 0.95218 & 0.00181 & 0.00363 \\
\hline & {$[0.80775]$} & {$[0.01524]$} & [1.19860] & {$[0.01157]$} & {$[0.01157]$} \\
\hline \multirow{2}{*}{$\Delta(\mathbf{C}(-1))$} & 0.66574 & 0.00433 & 1.04890 & 0.00433 & 0.00204 \\
\hline & [1.04184] & [0.01795] & [0.69205] & [0.01298] & [0.01308] \\
\hline \multirow{2}{*}{$\Delta(\mathrm{SE}(-1))$} & 0.90977 & 0.00312 & 0.79706 & 0.00367 & 0.00292 \\
\hline & [0.70619] & {$[0.00742]$} & [0.67467] & [0.01524] & [0.01505] \\
\hline \multirow{2}{*}{$\Delta(\operatorname{IFF}(-\mathbf{1}))$} & 0.83500 & 0.00292 & 1.02805 & 0.00433 & 0.00322 \\
\hline & [0.59801] & {$[0.01505]$} & [0.92198] & [0.01795] & [0.00869] \\
\hline \multirow{2}{*}{ C } & 0.15551 & 0.01951 & 0.15551 & 0.01428 & 0.03025 \\
\hline & [3.37947] & [1.78081] & [3.37947] & [1.86034] & [1.83901] \\
\hline R-squared & 0.85478 & 0.81256 & 0.84125 & 0.78545 & 0.76859 \\
\hline Adj. R-squared & 0.75874 & 0.75485 & 0.77458 & 0.65891 & 0.62584 \\
\hline
\end{tabular}

Source: Compiled by authors

The results of VECM modeling confirm the validity of the hypothesis of a long-term relationship between tax morale and indicators of tax competitiveness of the country. Thus, ECT coefficients are negative and statistically significant at $10 \%, 5 \%$, and $1 \%$ levels, and their values indicate a low rate of return of the system to long-term equilibrium under the influence of exogenous shocks. 


\section{Conclusions}

Tax morality is one of the determining factors in the functioning of the shadow sector of the economy and the formation of its international competitiveness. At the same time, the systematization of research results showed a low level of research on these issues. Most scholars view tax morality as a factor that is not quantified. It reduces the reliability of the results of determining the nature of the dependence of the country's development indicators on the level of tax morale of the population and the adequacy of the conclusions drawn. In this paper, with the help of econometric modeling tools, an assessment of the causal relationship of tax morale with indicators of tax competitiveness of the country is made. The results of the analysis confirmed the long-term relationship between them. The high level of tax morale in society leads to a decrease in the volume of shadow financial transactions and corruption. Taking into account these dependencies should serve as a basis for the implementation of measures to increase tax competitiveness, which are based on the use of both economic and institutional tools for regulating the economy.

Author Contributions: Conceptualization: Mazurenko O., Tiutiunyk I., Derkach L.; data curation: Mazurenko O., Tiutiunyk I., Derkach L.; formal analysis: Mazurenko O., Tiutiunyk I., Derkach L.; investigation: Mazurenko O., Tiutiunyk I., Derkach L.; methodology: Mazurenko O., Tiutiunyk I., Derkach L.; project administration: Mazurenko O., Tiutiunyk I., Derkach L.; resources: Mazurenko O., Tiutiunyk I., Derkach L.; software: Mazurenko O., Tiutiunyk I., Derkach L.; supervision: Mazurenko O., Tiutiunyk I., Derkach L.; validation: Mazurenko O., Tiutiunyk I., Derkach L.; visualization: Mazurenko O., Tiutiunyk I., Derkach L.; writing - original draft: Mazurenko O., Tiutiunyk I., Derkach L.; writing- review and editing: Mazurenko O., Tiutiunyk I., Derkach L.

Funding. This research was funded by the grant "Quadrocentric recursive model of de-shadowing of Ukraine's economy for growth of its macroeconomic stability" (0120U104798, funding - National Research Foundation, 2020-2021).

\section{References}

1. Doerrenberg, P., \& Peichl, A. (2018). Tax Morale and the Role of Social Norms and Reciprocity: Evidence from a Randomized Survey Experiment. CESifo Working Paper Series No. 7149, 40 p. [Google Scholar] [CrossRef]

2. Kirchgässne, G. (2011). Tax Morale, Tax Evasion, and the Shadow Economy. University of St. Gallen, Varnbüelstrasse. Discussion paper, 2010-17. [Google Scholar]

3. Scholz, J.T., \& Pinney, N. (1995). Duty, Fear, and Tax Compliance: The Heuristic Basis of Citizenship Behavior. American Journal of Political Science, 39(2), 490-512. [Google Scholar] [CrossRef]

4. Torgler, B. (2011). Tax morale and Compliance: review of evidence and case studies for Europe. World Bank Policy Research Working Paper 5922. World Bank, Washington DC. [Google Scholar] [CrossRef]

5. Weck, H. (1983). Schattenwirtschaft: Eine Möglichkeit zur Einschränkung der öffentlichen Verwaltung? [Shadow Economy: A Way to Restrict Public Administration?]. Lang, Frankfurt. 160 p. Available at: [Link]

6. Wenzel, M. (2005). Motivation or Rationalisation? Causal Relations Between Ethics, Norms, and Tax Compliance. Journal of Economic Psychology, 26(2005), 491-508. [Google Scholar] [CrossRef]

7. Tiutiunyk, I., Humenna, Yu. (2021). Role Of Financial Intermediaries in Shadow Schemes: Risk-Based Approach. Financial Markets, Institutions and Risks, 5(3), 87-92. [CrossRef]

8. Tiutiunyk, I., Zolkover, A., Maslov, V., Vynnychenko, N., Samedova, M., Beshley, Y., \& Kovalenko, O. (2020). Indices of innovation activity as components of macroeconomic stability: how does the shadowing of investment flows affect? Marketing and Management of Innovations, 4, 26-40. [Google Scholar] [CrossRef]

9. Salé, M.J., Muharremi, O., Hoxhaj, M. (2021). Albanian Individual Taxpayers Perceptions and Determinants on Ethical Behavior Regarding Tax Compliance. Business Ethics and Leadership, 5(1), 66-80. [Google Scholar] [CrossRef]

10.Tiutinyk, I., Mazurenko, O. (2021). The Theory of International Tax Competition: Comparative Analysis. SocioEconomic Challenges, 5(3), 134-138. [Google Scholar] [CrossRef]

11.Mazurenko, O., Tiutiunyk, I. (2021). The International Tax Competitiveness: Bibliometric Analysis. Financial Markets, Institutions and Risks, 5(1), 126-138. [Google Scholar] [CrossRef] 